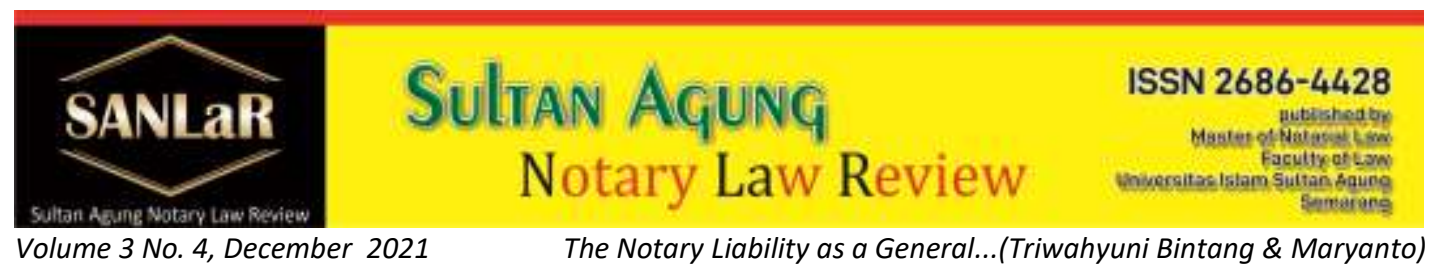

\title{
The Notary Liability as a General Officer in Making Banking Credit Agreements
}

\author{
Triwahyuni Bintang*) and Maryanto**) \\ *) Faculty of Law, Universitas Islam Sultan Agung (UNISSULA) Semarang, E-mail: \\ yunistar995@gmail.com
}
${ }^{* *}$ Faculty of Law, Universitas Islam Sultan Agung (UNISSULA) Semarang, E-mail: maryanto@unissula.ac.id

\begin{abstract}
The existence of a Notary must be impartial or neutral, so a Notary in making a deed may not involve himself in the deed, including the making of a deed for his family, also includes the prohibition of involving his family members as witnesses. If the Notary makes a technical error or is proven to have violated the Notary Position Act, from various sanctions depending on what mistakes were made by the Notary. If the Notary is asked by the client to provide the necessary information or advice related to the process of making the deed, if the information or advice given by the Notary is wrong or inappropriate and causes the client's loss, the Notary must be responsible as long as the information provided by the client is also true or not a lie. This study uses a sociological juridical approach.
\end{abstract}

Keywords: Notary; Deed; Credit; Agreement; Banking.

\section{Introduction}

Indonesia's economic development cannot be separated from the basic philosophy that underlies the activities of the state and nation, namely Pancasila and the 1945 Constitution and developed as a joint effort of all the people in a sustainable manner based on the principles of justice, efficiency, and economic democracy to realize prosperity, welfare, and social justice for all people. ${ }^{1}$

One of the important elements in the process of economic development is the role of banking. Banking institutions as the main source of financing are obliged to facilitate the development of the market economy. Banking financial institutions have an important and strategic role in moving the wheels of a

\footnotetext{
${ }^{1}$ Etty Mulyati, Kredit Perbankan (Aspek Hukum dan Pengembangan Usaha Mikro Kecil dalam Pembangunan Perekonomian Indonesia), PT Refika Aditama, Bandung, 2016, p. 1
} 
country's economy, banking institutions must be able to act as agents of development in an effort to find national goals and not become a burden and obstacle in the implementation of national development. ${ }^{2}$

The principle of freedom of contract contained in this article is universal. The principle of freedom of contract means that the parties can make any agreement, as long as it does not conflict with the law, public order, and morality. ${ }^{3}$

Credit funds from banks cannot be fully returned by the debtors in accordance with the agreed time, this can result in the credit journey being stopped or jammed. Bad credit is a condition where a debtor is unable to pay or return the loan as agreed. Every bank must face the problem of non-performing loans and bad credit is a risk of any lending, but as far as possible the bank should be able to avoid these problems.

For this reason, the Notary must be fully responsible for the correctness of the deed made before him in the banking credit agreement, which means:

a. Notaries are required to make the deed properly and correctly, meaning that the deed made fulfills the legal will and the request of interested parties because of their position.

b. A notary is required to produce a quality deed, meaning that the deed he makes is in accordance with the rule of law and the will of the interested party in the true sense, not making it up. The notary must explain to interested parties the truth of the contents and procedures of the deed he made.

c. A positive impact means that anyone will admit that the Notary deed has perfect evidence. ${ }^{4}$

In this regard, it is necessary to know that basically the form of a Notary deed which contains actions and other matters that are notarized by a Notary, generally must comply with the provisions contained in the applicable laws and regulations, regarding this matter, among others are regulated in the Civil Code and the Law on Notary Positions.

Against the material truth in the party deed if there is an error or it is contrary to what is actually stated in the Notary deed, it cannot be legally held liable. Specifically with regard to claims based on default, it is necessary to give an affirmation that the Notary in making the deed made before him cannot be sued based on the default because the work carried out by the Notary is not a work that was previously agreed with the client, but the work carried out on the basis of the elaboration of the provisions of the law. Notaries are not parties who must fulfill the provisions of the agreement made.

\footnotetext{
${ }^{2}$ Hermansyah, Hukum Perbankan Nasional Indonesia, Prenada Media Group, Jakarta, 2007, p.41. ${ }^{3}$ Subekti, Hukum Perjanjian, PT. Pembimbing Masa, Jakarta, 1972, p. 15.

${ }^{4} J o a n e s$ Ibrahim, Mengupas Tuntas Kredit Komersial Dan Konsumtif Dalam Perjanjian Kredit Bank (Perspektif Hukum dan Ekonomi), Mandar Maju, Bandung, 2004, p. 16-18.
} 
The existence of a notary must be impartial or neutral, so a notary in making a deed may not involve himself in the deed, including the making of a deed for his family, also includes the prohibition of including his family members as witnesses. So the notary only confirms the will of the parties, the notary is not in it, but is outside the parties. So it is impossible for a notary to make an authentic deed of his own volition without the presence of the parties, nor is it possible for a notary to say he canceled the deed made before him. If a deed made before or by a Notary contains a juridical defect which is solely due to the Notary's fault, the error can cause losses, the Notary must be responsible. But if the deed contains incorrect content, it is not the fault of the Notary, because the Notary's liability is only in the formal form of the deed required by law. While the contents are outside the responsibility of the Notary.

If the Notary makes a technical error or is proven to have violated the Notary Position Act, from various sanctions depending on what mistakes were made by the Notary. The sanctions range from verbal warning, written warning, temporary dismissal, honorable discharge or dishonorable discharge. In the event that the Notary makes a mistake, it turns out that if the cause is a dishonest client statement, the result is a loss for certain parties. , resulting in a loss. So it is the client who is responsible, not the Notary.

If the Notary is asked by the client to provide the necessary information or advice related to the process of making the deed, if the information or advice given by the Notary is wrong or inappropriate and causes the client's loss, the Notary must be responsible as long as the information provided by the client is also true or not a lie. On the other hand, if the Notary has given advice or advice at length and it turns out that the Notary's advice is an answer related to the information or statement given by the client to the Notary, even though the client's information is not true or false, the Notary cannot be held liable.

Based on the above background, the formulation of the problem in this study are: 1) How? Liability of a Notary in a Civil Perspective and Law on Notary Positions? 2) What is the position of a Notary in the Implementation of Liability for a Banking Credit Agreement? 3) How is the Legal Protection for Notaries Liability Related to Banking Credit Agreements?

\section{Research Methods}

The approach method used in this research is a sociological juridical approach. The sociological juridical approach is an approach with legal reality in society. The sociology of law approach is an approach used to look at legal aspects in social interactions in society, and serves as a support to identify and clarify findings of non-legal materials for research purposes or legal writing. ${ }^{5}$ This research is descriptive analytical. This research will describe the problems and

${ }^{5}$ Zainudin Ali, Metode Penelitian Hukum, (Jakarta: Sinar Grafika, 2014), p. 105 
facts related to the Notary's Liability in the Civil Perspective and the Law on the Position of the Notary Against the Material Truth in the Banking Credit Agreement.

\section{Results and Discussion}

\subsection{Liability of a Notary in a Civil Perspective and Law on Notary Positions}

The notary's liability is civil liability for the deed he made, in this case the responsibility for the material truth of the deed, in the construction of an unlawful act. Acts against the law here in the nature of active or passive. Active, in the sense of carrying out actions that cause harm to other parties. While passive, in the sense of not doing an act that is a must, so that the other party suffers a loss. So the elements of unlawful acts here are the existence of unlawful acts, the existence of errors and the losses incurred.

If in another position, namely one of the parties feels aggrieved from the deed made by a notary, then the party who feels aggrieved can file a lawsuit in the form of a claim for compensation to the notary concerned, with the obligation of the plaintiff, namely in the lawsuit it must be proven that the loss is the result of directly from a notarial deed. In both positions, the plaintiff must be able to prove what was violated by the notary, from the external, formal and material aspects of the notary deed. Thus, anyone who feels aggrieved by a deed can deny or deny the formal truth of the deed. Such denial or denial must be made by filing a lawsuit in a general court,

The strength of this material evidence provides certainty about the material of a deed, provides certainty that the official or the parties declare and do as contained in the deed. That what is stated in the deed is the truth so that it is valid evidence against the parties who made the deed or those who have rights and apply to the public, unless there is evidence to the contrary (tegenbewis). Information or statements that are poured or written in the official deed or statements of the parties given/delivered before a notary and the parties must be judged to be true. ${ }^{6}$

If you want to prove the material aspects of the deed, then the party concerned must be able to prove that the notary did not explain or state the truth in the deed, or the parties did not explain the truth in the deed, so that these things caused losses to the party concerned then reverse proof must be carried out to deny the material truth of a notarial deed.

6Ibid., p. 223 
Wirjono Projodikoro said that accountability for a person's actions usually only exists when that person commits acts that are not permitted by law or most of these acts are an act regulated in the BW which is called an unlawful act. ${ }^{7}$ An act against the law in a broad sense if the person's actions violate the rights of others.

Notaries who make mistakes in carrying out their duties cannot be separated from the existing sanctions. In this regard, various types of sanctions can be imposed depending on the nature of the wrong that has been committed. The sanctions that can be imposed are $^{8}$ :

a.

Civil Liability or Liability of the Notary Against the Material Truth of the Deed He Made

b.

Liability or Liability of a Notary Criminally Against the Material Truth in the Deed He Made

c. Administrative Liability or Liability of the Notary Against the Material Truth in the Deed He Made

d. The Notary's Liability or Liability Based on the Notary's Position Regulations Against the Material Truth in the Deed He Made

e. $\quad$ The Notary's Liability or Responsibilities in Carrying Out His Position Based on the Notary's Code of Ethics

In connection with the sanctions that can be accounted for by the Notary as mentioned above, of course, the Notary also has a deadline for accountability for the deed he made. In this case specifically for a notary, a substitute notary, a special substitute notary, and a temporary official whose responsibilities have limits according to the place and position of the office area. Based on the concept of such a position, a notary as a position (so that the legal rules regarding notaries, namely UUJN, not a notary profession law and not a notary profession law) have limitations in terms of their authority ${ }^{9}$.

\subsection{Position of Notary in the Implementation of Liability for Banking Credit Agreement}

\footnotetext{
7 http://wardanirizki.blogspot.sg/2013/10/tanggung-jawab-notaris-ditinjau-dari.html, accessed on 18 December 2016.

${ }^{8}$ A Chuasanga, Ong Argo Victoria. (2019). Legal Principles Under Criminal Law in Indonesia Dan Thailand, Jurnal Daulat Hukum, Vol 2, No 1 (2019) http://jurnal.unissula.ac.id/index.php/RH/article/view/4218

${ }_{9}$ Alam, Bahrul., \& Khisni, Akhmad. (2020). Legal Protection of Holders of Land Loss Data In The City Land Office of Kendari. JURNAL AKTA: Vol.7, No. 2, 159-164. Retrieved from http://jurnal.unissula.ac.id/index.php/akta/article/view/7963
} 
A notary as a trusted public official whose deeds can be strong evidence in the event of a legal dispute in court, a notary must uphold the dignity of his profession as a position of trust and carry out his duties appropriately and honestly, which means acting according to the truth in accordance with notary oath $^{10}$.

A notary is also a human being who does not escape from mistakes, whether intentional or due to negligence. This condition is also exacerbated by the large number of notaries who are in each working area so that it is possible for violations of the making of the deed to occur. Every act that violates the law must of course undergo a process of investigation, investigation, and trial as well as other legal processes, both civil and criminal ${ }^{11}$. Associated with such matters, often these problems fall into the realm of criminal law. Of course, this legal dispute does not only have implications for the Notary who made the deed, but can also have implications for the deed itself.

Therefore, the need for summons and the presence of a notary in the examination of a criminal case can be distinguished as follows:

\section{a. As an Expert.}

In this case a notary is summoned and his presence in criminal case examinations is necessary as a legal expert who is authorized to make an authentic deed so that special legal considerations are needed according to his expertise related to the authority and responsibility of a notary as well as matters that can provide explanations to Polri investigators, Public Prosecutors, judges, lawyers/legal advisors and justice seekers.

\section{b. As a Witness.}

In this case, a notary is summoned and his presence in the examination of a criminal case is required, in his capacity as a public official who makes an authentic deed, his testimony is needed against what he saw, heard and supporting evidence in making the authentic deed, which turned out to be a

\footnotetext{
${ }^{10}$ Arrohim, Mohammad B., \& Wahyuningsih, Sri Endah. (2020). Analysis of Judicial Application of Criminal Penalty Against Notary / Land Deed Officials Conducting Making Crime of the Fake Authentic Deed in State Court of Semarang. JURNAL AKTA: Vol.7, No. 2, 183-188. Retrieved from http://jurnal.unissula.ac.id/index.php/akta/article/view/7891

${ }^{11}$ Deen, Thaufiq., Ong Argo Victoria \& Sumain. (2018). Public Notary Services In Malaysia. JURNAL AKTA: Vol. 5, No. 4, 1017-1026. Retrieved from http://jurnal.unissula.ac.id/index.php/akta/article/view/4135
} 
criminal case. In this position as a witness, if there is a strong suspicion that a notary is involved, his status can be increased to become a suspect.

\section{c. As a suspect.}

In this case, a notary is summoned and his presence in a criminal case examination is necessary as a suspect based on preliminary evidence so that deservelt is suspected that there was a crime committed by a notary as an authentic deed maker, either alone or jointly, which was found by the investigator, so that the notary must be held accountable for the act in the trial. With regard to a notary who is a defendant in a criminal case, for this reason, the author proposes a comparison of forms of legal protection before the Constitutional Court Decision Number 49/PUU-X/2012.

Likewise, the provisions of Article 1909 paragraph (2) of the Civil Code and the provisions of Article 322 paragraph (1) of the Criminal Code. However, if these provisions are understood, then what must be kept confidential are only those that are entrusted to him because of his position, work and position.

Legal protection for notaries in carrying out their duties as Public Officials is regulated in Act No. 30 of 2004 concerning Notary Positions, which are specifically related to the making of deeds as regulated in the provisions of Article 4 paragraph (2) and Article 16 paragraph (1) letter e regarding the obligation of a notary to maintain the confidentiality of the deed he made is to protect the interests of all parties related to the deed he made.

Therefore, in accordance with the provisions of Article 16 paragraph (1) letter b, a notary is obliged to make a deed in the form of a minutes of deed and keep it as part of the notary protocol. This is intended to maintain the authenticity of a deed. So that if there is a forgery or misuse of grosse, a copy, or a quote can be immediately identified easily by matching it with the original. Notaries can only provide, show, or notify the contents of the deed, grosse deed, copy of the deed or excerpt of the deed, to people who have a direct interest in the deed, heirs, or people who have rights, unless otherwise stipulated by laws and regulations, this is in accordance with the provisions of Article 54 of Act No. 30 of 2004 concerning the Position of a Notary.

In giving, showing, or notifying the contents of the deed, a notary can give, show, or notify:

a. Persons with direct interest in the deed;

b. Heir; or 


\section{c. People who have rights.}

The definition of "person who has the right" is not explained or described in the Law on Notary Positions, so it will also lead to multiple interpretations. One of them is when someone who feels that his rights have been harmed due to an alleged false deed or false information in the deed, then that person makes a Report / Complaint to the Indonesian Police. By making a Report/Complaint to the Indonesian Police, the Police investigator is the "person who has the right" to see and know the contents of the deed, grosse deed, copy of deed or deed excerpt, whether the deed is fake or whether there is false information in the deed will be able to immediately easily known and matched with the original ${ }^{12}$. However, the National Police Investigator as "the person who has the right" to see and know the contents of the deed, grosse deed,

This is what the author mentions as "Other Privileges" from a notary, so that it will be difficult for Polri investigators to reveal/investigate "whether the Deed is False" or "whether there is False Information in the deed" by matching it to the original.

Legal protection for the notary is also regulated technically in the Regulation of the Minister of Law and Human Rights Number: M.03.HT.03.10 of 2007. In CHAPTER III of the Minister of Law and Human Rights, it is regulated on the Terms and Procedures for Taking Minuta of Deeds and/or Letters Placed on the Minutes of Deed or Notary Protocol in the Notary's Depository ${ }^{13}$.

\subsection{Legal Protection for Notaries Responsible for Banking Credit Agreements}

The model of legal protection for notaries who carry out accountability according to the author's research is before the decision of the Constitutional Court NO 49/PUU-X/2012 is the same as the Minister of Law and Human Rights Regulation number 7 of 2016, that the legal efforts of the Notary Supervisory Council (MPN) for summons and examination by Polri investigators against notaries who commit criminal acts, namely by providing legal protection. Legal protection for notaries in carrying out their duties as Public Officials, both before and after the Decision of the Constitutional Court of the Republic of Indonesia Number

12 Ong Argo Victoria, (2018) Waqf Al-Nuqūd In Indonesia (In Law Perspective), Jurnal Pembaharuan Hukum Vol 5, No 1 Universitas Sultan Agung, http://jurnal.unissula.ac.id/index.php/PH/article/view/2999 -19 Pandemic. KnE Social Sciences, 5(1), 598-618. https://doi.org/10.18502/kss.v5i1.8317

13 Sukarmi, S., \& Victoria, A. (2018). Cash Waqf in Sustaining Of Indonesian Society "In Legal \&amp; Economic Perspective". AL-ITQAN: JOURNAL OF ISLAMIC SCIENCES AND COMPARATIVE STUDIES, 2(1), 83-97. https://doi.org/10.31436/al-itqan.v2i1.43 
49/PUU-X/2012, dated 28 May 2013 is the SAME, as stipulated in Act No. 30 of 2004 concerning Positions. Notary and related to the making of the deed carried out by a notary, The Notary Position Act provides legal protection to notaries as contained in the provisions of Article 4 paragraph (2) regarding the Notary Oath / Promise, one of which reads "...that I will keep the contents of the deed and information obtained in the exercise of my position secret...". It is further regulated in the provisions of Article 16 paragraph (1) letter e, which reads "...In carrying out his/her position, a Notary is obliged to: e. keep everything about the deed he made and all information obtained for the making of the deed in accordance with the oath/promise of office, unless the law stipulates otherwise...". It is further regulated in the provisions of Article 16 paragraph (1) letter e, which reads "...In carrying out his/her position, a Notary is obliged to: e. keep everything about the deed he made and all information obtained for the making of the deed in accordance with the oath/promise of office, unless the law stipulates otherwise...". It is further regulated in the provisions of Article 16 paragraph (1) letter e, which reads "...In carrying out his/her position, a Notary is obliged to: e. keep everything about the deed he made and all information obtained for the making of the deed in accordance with the oath/promise of office, unless the law stipulates otherwise...".

However, what is different is the procedure for legal protection of a notary in carrying out his duties as a public official. Based on the Decision of the Constitutional Court of the Republic of Indonesia Number 49/PUU-X/2012, dated May 28, 2013, the procedures stipulated in Article 66 paragraph (1) of the Law on Notary Positions are technically regulated in the Regulation of the Minister of Law and Human Rights Number : M.03.HT.03.10 Year 2007 is no longer valid. Investigator or Public Prosecutor or Judge in taking a photocopy of the Minutes of Deed and/or letters attached to the Minutes of Deed or Notary Protocol in the notary's depository; and summoning a notary to attend an examination related to the deed he made or the Notary Protocol that is in the notary's deposit is no longer necessary "with the approval of the Regional Supervisory Council".

This is actually not something to be worried about, if the notary in carrying out his duties acts in accordance with the applicable laws and regulations and in accordance with the existing code of ethics. In addition, the notary also still has the "RIGHT to deny" which is also the "Obligation to deny" in dealing with the efforts of interested parties, including investigators, public prosecutors or judges.

The right of refusal is the right owned by a notary not to answer questions from investigators, public prosecutors, or judges, when examined or asked for information on problems that arise in the notarial deed he made. information before investigators, public prosecutors or judges related to the secret of his 
position, namely regarding matters entrusted to him because of his position, work and position, based on the provisions of Article 170 paragraph (1) of the Criminal Code, Article 1909 of the Civil Code and the provisions of Article 322 paragraph (1) KUHP.

Based on The right of denial, the notary can still maintain the confidentiality of everything regarding the deed he made and all information obtained for the making of the deed. There are concerns from the notary community about "arbitrary actions" from unscrupulous investigators, so it is better to make a rule regarding the procedure for summoning and examining notaries, either as witnesses or suspects. This is also in line with the Memorandum of Understanding (MoU) between the Indonesian National Police (Polri) and the Indonesian Notary Association (INI) No. Pol: B/1056/V/2006 and Number: 01/MOU/PP-INI-/V/2006 concerning Development of Professionalism Improvement in the Field of Law Enforcement, dated May 9 2006, in particular the provisions of Article 1 paragraph (2) which states that legal actions taken by investigators (Investigators) as referred to in paragraph (1) in the form of summons.

\section{Closing}

1) Characteristics of a Notary Banking Credit Agreement include, the background to be agreed upon, identification of the parties (legal subjects), identification of the object to be agreed upon, making the deed framework, formulating the substance of the deed, which consists of (the position of the parties, the boundaries (which may or may not be) not allowed) according to the rule of law, Things that are limited in their implementation Choice of law and choice of court, Clause of dispute resolution, Relation to other deeds (if any). 2) Liability from the cancellation of a deed as a notary deed can cause the notary to be obliged to pay fees, compensation and interest as well as fines. So basically a client who feels aggrieved by the unlawful act of a Notary can claim compensation. The demands can be in the form of: Compensation in the form of money for the losses incurred, Compensation in kind or returned in its original state, Statement that the act committed is against the law. Forbidding the doing of certain acts. In addition, the Notary's liability for the deed he made can continue until the Notary's last breath. 3) Legal protection for notaries in carrying out their duties as Public Officials, both before and after the Decision of the Constitutional Court of the Republic of Indonesia Number 49/PUU-X/2012, dated 28 May 2013 is the SAME, as stipulated in Act No. 30 of 2004 concerning Positions. Notary and related to the making of a deed carried out by a notary, the Notary Position Act provides legal protection to notaries as contained in the provisions of Article 4 paragraph (2) concerning the Oath / Promise of a Notary. 


\section{References}

Journals:

[1] A Chuasanga, Ong Argo Victoria. (2019). Legal Principles Under Criminal Law in Indonesia Dan Thailand, Jurnal Daulat Hukum, Vol 2, No 1 (2019) http://jurnal.unissula.ac.id/index.php/RH/article/view/4218

[2] Alam, Bahrul., \& Khisni, Akhmad. (2020). Legal Protection of Holders of Land Loss Data In The City Land Office of Kendari. JURNAL AKTA: Vol.7, No. 2, 159-164. Retrieved from http://jurnal.unissula.ac.id/index.php/akta/article/view/7963

[3] Arrohim, Mohammad B., \& Wahyuningsih, Sri Endah. (2020). Analysis of Judicial Application of Criminal Penalty Against Notary / Land Deed Officials Conducting Making Crime of the Fake Authentic Deed in State Court of Semarang. JURNAL AKTA: Vol.7, No. 2, 183-188. Retrieved from http://jurnal.unissula.ac.id/index.php/akta/article/view/7891

[4] Deen, Thaufiq., Ong Argo Victoria \& Sumain. (2018). Public Notary Services In Malaysia. JURNAL AKTA: Vol. 5, No. 4, 1017-1026. Retrieved from http://jurnal.unissula.ac.id/index.php/akta/article/view/4135

[5] Ong Argo Victoria, (2018) Waqf Al-Nuqūd In Indonesia (In Law Perspective), Jurnal Pembaharuan Hukum Vol 5, No 1 Universitas Sultan Agung, http://jurnal.unissula.ac.id/index.php/PH/article/view/2999

[6] Sukarmi, S., \& Victoria, A. (2018). Cash Waqf in Sustaining Of Indonesian Society "In Legal \&amp; Economic Perspective". AL-ITQAN: JOURNAL OF ISLAMIC SCIENCES AND COMPARATIVE STUDIES, 2(1), 83-97. https://doi.org/10.31436/al-itqan.v2i1.43

Books:

[1] Amirudin dan H. Zaenal Asikin, Pengantar Metode Penelitian Hukum (Jakarta: RajaGrafindo Persada, 2008)

[2] Banakar, Reza dan Max Travers, Law, Sociology and Method dalam Reza Banakar \& Max Travers (ed), Theory and Method in Socio-Legal Research,(Onati: Hart Publishing Oxford and Portland Oregon,2005)

[3] Hakim Amrie,"Unsur - Unsur Pidana yang Dihadapi Notaris dalam Menjalankan Jabatannya"

[4] Mahmud Peter Marzuki, Penelitian Hukum, ed. 1,( Jakarta: Prenada Media, 2005)

[5] Mukti Fajar Nur Dewata dan Yulianto Achmad, Dualisme Penelitian Hukum Normatif dan Empiris (Yogyakarta; Pustaka Pelajar, 2010), hlm 104 
[6] Rosady Ruslan, Metode Penelitian Public Relations dan Komunikasi, (Jakarta: Rajawali Pers, 2003)

[7] Soerjono Soekanto, Pengantar Penelitian Hukum, cet 3,(Jakarta; UI Oress, 2004)

[8] Suteki, Desain Hukum di Ruang Sosial, Thafa Media, Yogyakarta, 2014

[9] Tobing, Lumban S.H., Peraturan Jabatan Notaris, Erlangga, Bandung, 1983.

[10] Tedjosaputro, Liliana, Etika Profesi Notaris dalam penegakkan Hukum Pidana,(Yogyakarta; Bigraf Pulishing, 1995)

Regulations:

[1] Act No. 2 of 2014 concerning Amendments to Act No. 30 of 2004 concerning the Position of Notary.

[2] Civil Code.

[3] Constitutional Court Decision No. 49/PUU-X/2013.

[4] Criminal Code

[5] Minister of Law and Human Rights Regulation No. 7 of 2016.

[6] Regulation of the Minister of Law and Human Rights Number: M.03.HT.03.10 of 2007 concerning the Taking of Minutes of Deed and Summoning of Notaries.

Internet:

[1] http://www.hukumonline.com/klinik/detail/cl5135/unsur-unsur-pidanayang-dihadapi-notaris-dalam-menjalankan-jabatannya,

[2] Widhi Handoko, Contoh Penulisan Proses Penelitian Dalam Metode Penelitian, widhihandoko.com/?tag=socio-legal, accessed on 13 October 2016 www.mahkamahkonstitusi.go.id/28Agustus2015.

[3] Zulpiero.wordpress.com.hubungan-peraturan-jabatan-notaris-dan-kodeetik-dalam-pelaksanaan-tugas-notaris. 